\title{
DEVELOPMENTAL PATTERNS OF GLYCOLYTIC ENZYMES IN REGENERATING SKELETAL MUSCLE AFTER AUTOGENOUS FREE GRAFTING*
}

\author{
K R WAGNER ${ }^{1}$, B M CARLSON ${ }^{2}$ and S R MAX ${ }^{1}$ \\ 1 Department of Neurology and Pediatrics, University of Maryland School of Medicine, Baltimore, \\ Md 21201 ard $^{2}$ Department of Anatomy, University of Michigan School of Medicine, Ann Arbor, \\ Mich 48109 (US A)
}

(Received 25 May, 1977)

\section{SUMMARY}

Extensor digitorum longus muscles of rats were removed and injected with a solution of Marcaine plus hyaluronidase After incubation in Marcaine solution for $10 \mathrm{~min}$, the muscles were grafted into their original beds The grafts and the contralateral control muscles were removed from the rats at $0,1-5,7,11,36$, and 69 days postoperatively The muscles were then frozen in dry ice and ssopentane and subsequently homogenized and centrifuged The supernatant was analyzed for a number of enzymes, the regenerative patterns of which can be classified into 3 groups (1) early increase in actıvity hexokınase, glucose-6-phosphate dehydrogenase, (2) early decrease in activity with failure to recover to control levels phosphorylase, phosphofructokınase, $a$-glycerophosphate dehydrogenase, and (3) early decrease followed by return to control levels lactate dehydrogenase, pyruvate kınase, creatıne phosphokınase, adenylate kınase These patterns are not identical to those reported for embryogenesis of muscle The data are discussed with regard to correlative histological studies of muscle regeneration

\section{INTRODUCTION}

The regeneration of mammalian skeletal muscle follows a characteristic sequence of events After injury, the sarcoplasm of the muscle fiber begins to degenerate The principal changes are swellıng and internal alterations of mitochondria, distortion of myofilamentous organization, particularly in the area of the $\mathrm{Z}$ lines, and the appear-

* Supported by grants from the Muscular Dystrophy Association, Inc, and NIH (1 R01 NS 13116 and NS 11342) 
ance of abnormal membranous structures (Reznık 1973. Neerunjun and Dubowils 1974a. Mastaglia, Dawkıns and Papadımıtriou 1975) Regeneration is heralded b; activation of nuclei beneath the basement membrane of the muscle tiber, as indicated in autoradiographic studies by nuclear incorporation of labelled thymidine and uridine (Reznık 1968, Carlson 1972, Snow 1977a,b) Before these actıvated myoblastıc nucle develop further, sarcolysis of the original muscle fibers must occur In mammalian muscle sarcolysis is accomplished primarily by the activities of phagocytic cells, the majority of which appear to be derived from the blood The myoblastic cells then undergo a characteristic sequence of steps in cytodifferentiation, first into myotubes and later into cross-striated muscle fibers After neuromuscular contacts are established, the initially homogeneous population of regeneratıng muscle fibers undergoes a find differentiation into distinct groups, which have contractıle and histochemical properties related to their innervation

The timing, and to some extent, the sequence of early events in the degenerativeregenerative process depends upon the degree to which the blood supply to the muscle is affected by the initial traumatic event In some experimental models the blood supply around the damaged muscle fibers is relatively little affected, and degeneration and early regeneration of muscle are rapid In other models the damaged muscle is initially divorced from a direct blood supply, often for several days This prolongs the degeneratıve phase and delays the onset of regeneration in the damaged muscle because the sarcolytic phase does not occur untıl a local blood supply is re-established

Biochemical studies on early phases of muscle regeneration have been hampered by lack of homogeneity of the material to be analyzed In some experımental models, damaged and undamaged muscle fibers cannot be readily separated In other models large areas of degeneratıng origınal muscle fibers are found alongside regions containıng a hıghly asynchronous population of regeneratıng muscle fibers, with several different developmental stages represented sımultaneously (Carlson 1972)

Recently, Marcaine, a highly myotoxic local anesthetic agent (Benoit and Belt 1970, Jirmanova and Thesleff 1972), has proven to be of considerable use in the analysis of muscle regeneration (Max and Rifenberick 1975, Max and Albuquerque 1975. Hall-Craggs and Singh-Seyan 1975) Employing a series of intramuscular injections of Marcaıne plus hyaluronıdase extendıng over 3 days, Hall-Craggs (1974) obtained essentially complete degeneration and regeneration of the tıbıalıs anterior muscle in rats, although similar treatment of the rat extensor digitorum longus muscle allowed survival of significant numbers of muscle fibers (Carlson, unpublished observations) The combination of Marcaine treatment plus free graftıng of the extensor digitorum longus muscle in the rat produces a model in which virtually all the original muscle fibers are destroyed and replaced by a largely homogeneous population of regenerating muscle fibers with a minimal increase in the formation of new connective tissue (Carlson 1976) This model seems ideally suited for biochemical studies of skeletal muscle regeneration

In the present study, we examined two major questions concerning muscle regeneration The first is whether regenerating muscle is identical to embryonic muscle with regard to biochemical aspects of differentiation, the second concerns the source 
of metabolıc energy which permits survival of degeneratıng fibers and supports subsequent regeneration Previous work from this laboratory, employing the model of Marcaine-induced muscle regeneration described by Hall-Craggs (1974), suggests that glycolysıs, rather than oxıdatıve metabolısm, is a lıkely candıdate for this role (Rifenberıck, Koskı and Max 1975, Wagner, Max, Grollman and Kosk1 1976) Thus, we studied developmental patterns of a number of enzymes involved in glucose metabolism and compared our results with published enzyme patterns of muscle developing in vivo and in vitro Among the enzymes studied are the regulatory enzymes phosphorylase, hexokınase, phosphofructokınase, pyruvate kınase, and glucose-6-phosphate dehydrogenase Lactate dehydrogenase and $\alpha$-glycerophosphate dehydrogenase were included because of their respective roles in anaerobic metabolism of muscle and in oxıdation of extramitochondrial NADH Creatıne kınase and adenylate kınase were measured because of their well-known functions in the energy metabolism of muscle, and because they have been extensively studied in developing systems These data have been presented in prelımınary form (Wagner, Carlson and Max 1976)

\section{MATERIALS AND METHODS}

This study was carried out on 66 male Sprague-Dawley rats (175-200 g) obtained from Spartan Farms, Haslett, Michigan Other materials and their sources were $\mathrm{NADH}, \mathrm{NADP}^{+}$, ATP, phosphoenolpyruvate, 5'-AMP, Tris-HCl, glycogen, fructose6-phosphate, mercaptoethanol, aldolase, $\alpha$-glycerophosphate dehydrogenase, triosephosphate isomerase, dihydroxyacetone phosphate, dithıthreitol, glucose-6-phosphate dehydrogenase, hexokınase, glucose-1-phosphate, glucose-6-phosphate, lactate dehydrogenase, phosphocreatıne, hıstıdıne, hyaluronıdase (Sıgma), glucose, $\mathrm{MgCl}_{2}$, $\mathrm{KCl}, \mathrm{KF}$, toluene (Fisher Scientıfic), [U-14 C]glucose-1-phosphate (Amersham Searle), PPO, POPOP (New England Nuclear), Tenbroeck tissue homogenizers (Kontes Glass Company), Marcaine (Bupıvacaine) (Wınthrop Laboratories)

\section{Treatment of muscles}

During all surgical procedures, rats were anesthetızed with ether Immediately upon removal, the right extensor digitorum longus muscle was injected with as much Marcaine solution $(075 \%$ Marcaine in $09 \% \mathrm{NaCl}$ with 300 units of hyaluronidase per $\mathrm{ml}$ ) as it could hold (usually 100-200 $\mu \mathrm{l}$ ) The muscle was then soaked in Marcaine solution for $10 \mathrm{~min}$ to ensure exposure of peripheral muscle fibers to the damaging effects of the anesthetic agent The muscle was immediately grafted back into its own bed and sutured to its proximal and distal tendons No attempt was made to reestablısh nervous or vascular contınuity between the graft and the host In each anımal the left extensor digitorum longus muscle was untouched and served as a normal control At selected post-operative intervals $(0,1-5,7,11,36$ and 69 days), both the graft and its contralateral intact counterpart were removed from each of 6-7 rats The muscles were weighed and immediately immersed in a mixture of dry ice and isopentane They were kept contınuously frozen on dry ice durıng the 2-day shıppıng perıod from 
Michigan to Maryland Immediately upon arrival, muscles were minced with scissors in ice-cold $005 \mathrm{M}$ Tris- $\mathrm{HCl}$, pH 76 , contanning $020 \mathrm{mM}$ dithiothreitol (DTT) The finely mınced muscles were then homogenızed $(110, \mathrm{w} / \mathrm{v})$ by hand, usıng a Tenbroec $\mathrm{k}$ homogenizer The homogenate was centrifuged at 18,000, $g$ for 20 mın at 4 C Enzymes were assayed in the resulting supernatants

\section{Histological analysts}

Grafted muscles from a parallel series of rats were examined at each of the times when muscles were removed for biochemical analysis These grafts were fixed in Bouin's solution for histological study, and were then cut at $7 \mu \mathrm{m}$ and stained in Ehrlich's hematoxylın and eosin

\section{Enzyme assays}

The following enzymes were assayed at $25^{\circ} \mathrm{C}$ in a reaction volume of $10 \mathrm{ml}$ by monitoring the change in NADH or NADPH absorbance at $340 \mathrm{~nm}$ using a Beckman model 25 spectrophotometer hexokınase (2 711 ) (Uyeda and Racker 1965), phosphofructokinase (2 7 11) (Uyeda and Racker 1965, Paetkau and Lardy 1967), cytoplasmic a-glycerophosphate dehydrogenase (1 1118 ) (Holloszy and Oscal 1969), pyruvate kınase (2 71 40) (Shonk and Boxer 1964) Lactate dehydrogenase (1 11127 ) was assayed in the direction of pyruvate synthesis, employıng $190 \mathrm{mM}$ hydrazine sulfate

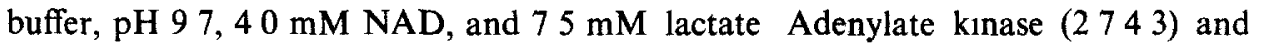
creatıne kınase (2732) were assayed in a medium contaınıng $25 \mathrm{mM}$ Trıs- $\mathrm{HCl}$, pH $81,10 \mathrm{mM} \mathrm{MgCl}$, $05 \mathrm{mM}$ DTT, $05 \mathrm{mM}$ NADP, $10 \mathrm{mM}$ glucose, $05 \mathrm{mM}$ ADP, 10 unit of hexokınase, and 10 unit of glucose-6-phosphate dehydrogenase To measure creatine kinase activity $50 \mathrm{mM} 5$ '-AMP was added to inhibit adenylate kınase (Smith 1972) after which $100 \mathrm{mM}$ phosphocreatıne was added Glucose-6phosphate dehydrogenase $\left(\begin{array}{llll}1 & 1 & 1 & 49\end{array}\right)$ was assayed in a medium containing $50 \mathrm{mM}$ Tris- $\mathrm{HCl}, \mathrm{pH} 81,30 \mathrm{mM}$ glucose-6-phosphate and $05 \mathrm{mM}$ NADP Total glycogen phosphorylase $(2411)$ was determined in the direction of glycogen synthesis in a

TABLE 1

\section{ENZYME ACTIVITIES OF CONTROL MUSCLES}

Enzymes were assayed as described in the text

\begin{tabular}{lr}
\hline Enzyme & $\begin{array}{l}\text { Specific activity } \\
\text { (nmol/min/mg protein) }\end{array}$ \\
\hline Phosphorylase & $9736 \pm 671$ \\
Hexokınase & $133 \pm 09$ \\
Phosphofructokınase & $6884 \pm 408$ \\
Pyruvate kınase & $35849 \pm 2676$ \\
Lactate dehydrogenase & $23851 \pm 1963$ \\
Glucose-6-phosphate dehydrogenase & $22 \pm 02$ \\
a-Glycerophosphate dehydrogenase & $6415 \pm 595$ \\
Adenylate kınase & $57241 \pm 4429$ \\
Creatıne kinase & $42911 \pm 1061$
\end{tabular}


reaction medium containıng $10 \%(\mathrm{w} / \mathrm{v})$ glycogen and $100 \mathrm{mM}\left[\mathrm{U}-{ }^{14} \mathrm{C}\right] \mathrm{glucose}-1-$ phosphate as substrates plus $20 \mathrm{mM} \mathrm{5}$-AMP and $100 \mathrm{mM} \mathrm{KF}$ The reaction was started with the addition of supernatant and stopped by spotting $80 \mu \mathrm{l}$ of the reaction mixture on Whatman 31 ET filter paper and carrying the papers through the ethanol washıng procedure of Thomas, Schlender and Larner (1968) (B I Brown, personal communication) The filter papers were then placed in counting vials containing liquifluor and counted in a Beckman LS 235 liquid scintillation counter Protein was determined by the method of Lowry, Rosebrough, Farr and Randall (1951)

\section{Expression of data}

Under our assay conditions, enzyme activities were linear with respect to tıme and protein concentration Enzyme specific actıvitıes were calculated as $\mathrm{nmol} / \mathrm{mın} / \mathrm{mg}$ protein and then expressed as average percentage of contralateral control $\pm \mathrm{S} \mathrm{E} \mathrm{M}$ Control values are given in Table 1

\section{RESULTS}

The wet weights of muscle grafts provided a good indication of both the course of regenerative activity within the graft and the overall physiological environment of which the graft is a part (Fig 1) Durıng the first day or two after graftıng, the muscle transplant and the surrounding tissues were markedly edematous Although degenerative changes were obvious in the muscle fibers throughout the graft, sarcolysis was mınımal except in a few muscle fibers at the extreme perıphery ( $F_{1} g$ 2) The com-

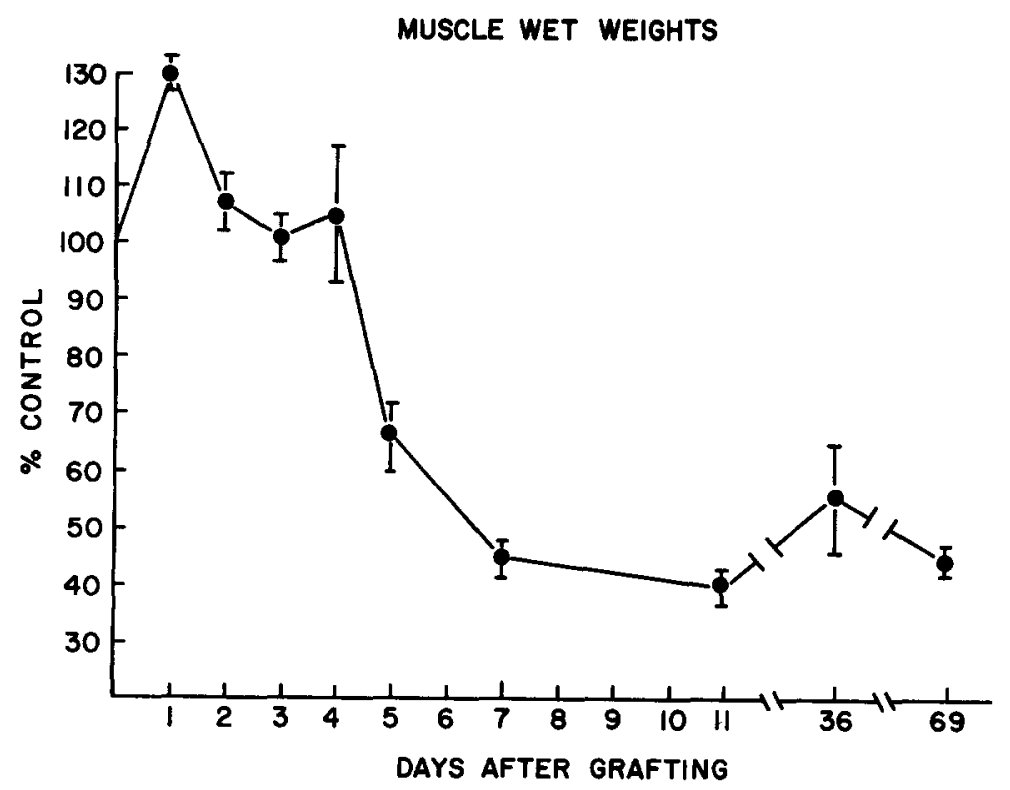

Fig 1 Fresh weights of rat extensor digitorum longus muscles after Marcaine treatment and orthotopic free grafting Values are means \pm S E M Numbers in parentheses are numbers of rats Experimental procedures are described in the text 


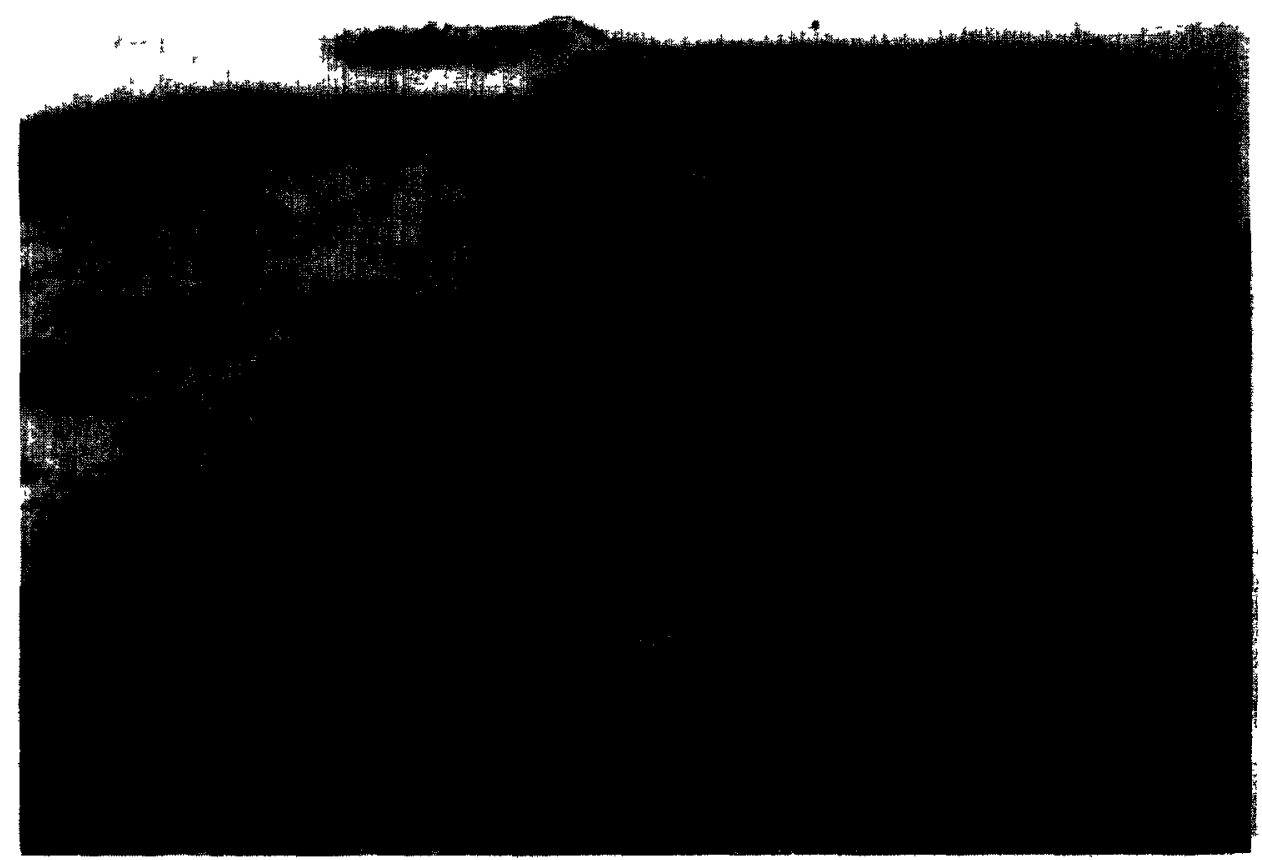

Fig 2 Cross-section through a one-day graft of Marcaine-treated muscle Fragmentation has begun in some of the peripheral muscle fibers $\mathrm{H}$ and $\mathrm{E}, \quad 100$

bination of acute postoperative edema plus lack of fragmentation of most of the degeneratıng fibers withın the graft caused the grafts to be heavier than normal contralateral muscles during the early postoperative days (Fig 1)

On the first day after grafting, the muscle was completely divorced from a blood supply and contained a homogeneous population of ischemic mature muscle fibers Durıng the second and thırd postoperatıve days the degeneratıng muscle fibers at the periphery of the graft underwent fragmentation Individual myoblastic cells became activated beneath the basement membranes of the degenerated original muscle fibers The ischemic muscle fibers in the central part of the graft (approximately $80 \%$ of the total number) had not yet undergone fragmentation

By the fourth day a well-defined centripetal gradient of regeneration and degeneration had been set up Surviving muscle fibers rarely persisted (mean of 22 surviving fibers per graft, Carlson 1976), at the extreme perıphery of the grafts Early myotubes were found at the periphery of the graft Toward the center myoblasts lined the basement membranes remainıng after degeneration of the muscle fibers In some 4-day grafts a small mass of ischemic, but intact, muscle fibers persisted in the center In other 4-day grafts all of the original muscle fibers had undergone sarcolysıs Five-day grafts were in the peak of the myotube stage (Fig 3) However, because of the radial gradient of differentiation, early cross striations could be seen in some of the most perıpheral regeneratıng muscle fibers whereas in the central regions late myoblasts or early myotubes still persisted

Because of the decline in the edema reaction and the complete sarcolysis of the 


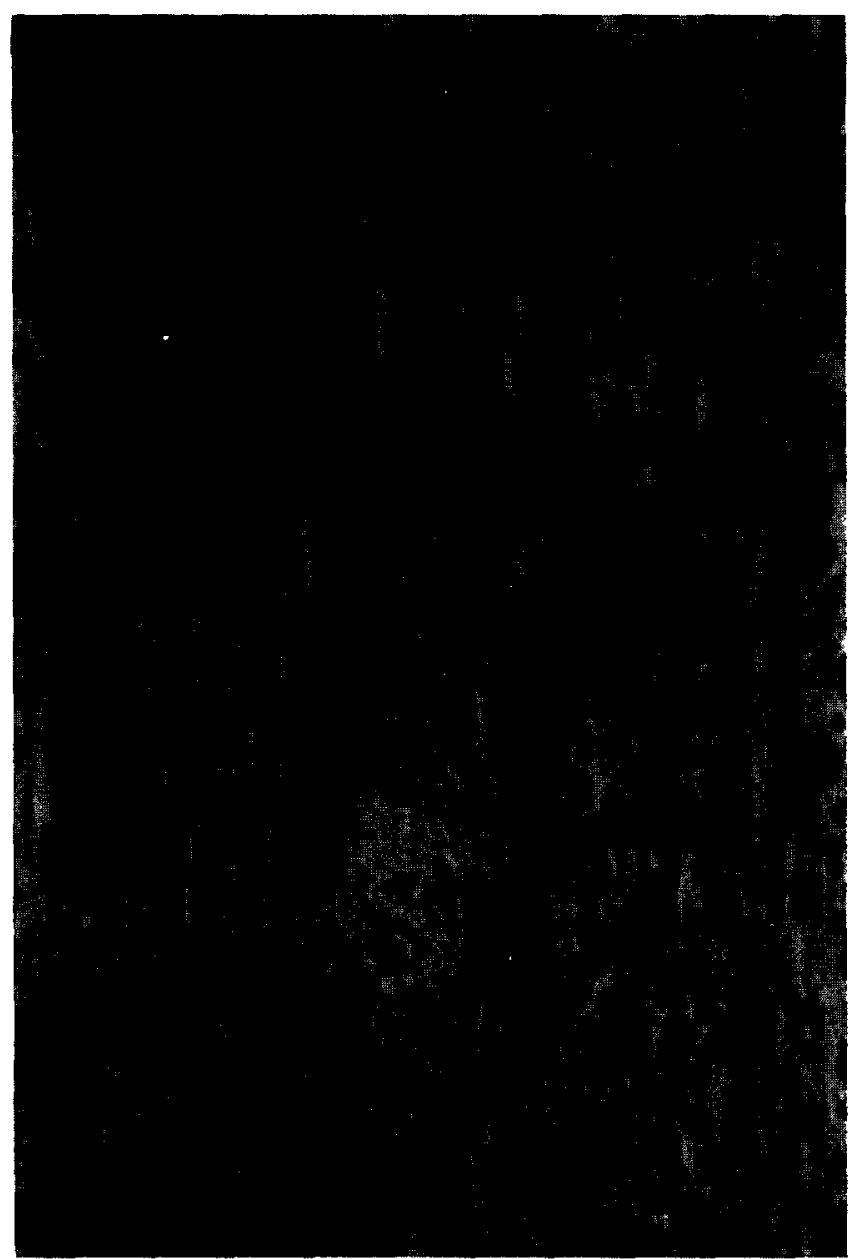

Fig 3 Longitudinal section through a 5-day muscle graft The regenerating muscle fibers are in the myotube stage A cross-section through the muscle graft revealed 3 surviving original muscle fibers $\mathrm{H}$ and $\mathrm{E}, \times 100$

original muscle fibers, the weights of the grafts declined precipitously untıl they were commonly about $40 \%$ of the contralateral normal muscles at the end of the first week (Fig 1) By 7-8 days the grafts were composed of a homogeneous population of young muscle fibers (Fig 4) capable of contracting (Carlson and Gutmann 1976)

As the regenerating muscle fibers matured, their cross sectional areas increased progressively (Mong 1976), and the relatıve weights of the grafts rose correspondingly Mature grafts (Fig 5) became stable at about $50 \%$ of the weight of control muscles (Fig 1)

Glucose-6-phosphate dehydrogenase actıvity began to increase on the first day after graftıng, attained a maxımum of 7 tımes the control actıvity by 8 days, and then gradually decreased (Fig 6a) Hexokınase activity decreased to $26 \%$ of control on the first day after graftıng and subsequently increased to about 15 tımes control by 


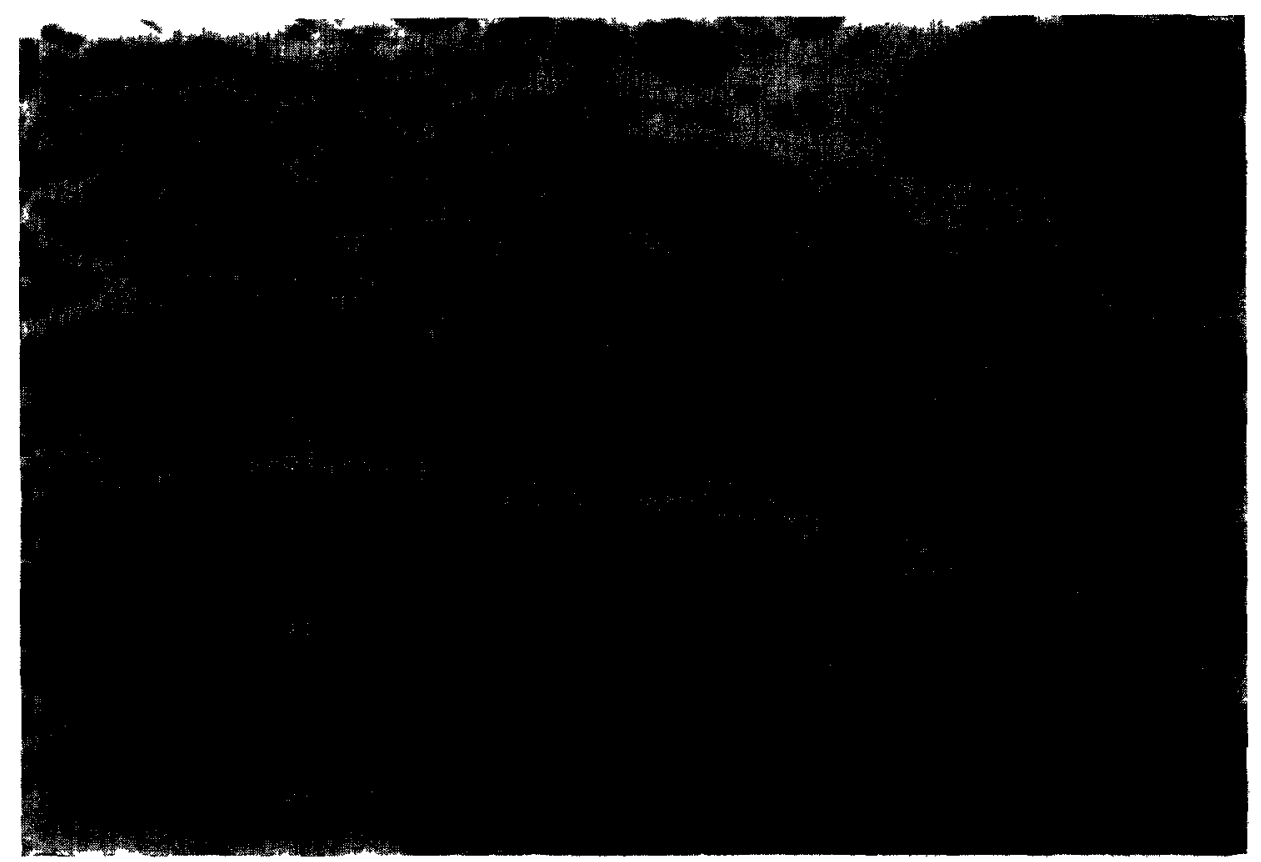

Fig 4 Cross-section through an 8-day muscle graft All of the muscle fibers in this section are $k$ generating and are undergoing transformation from myotubes to early cross-striated muscle fiber, $\mathrm{H}$ and $\mathrm{F}$, 100

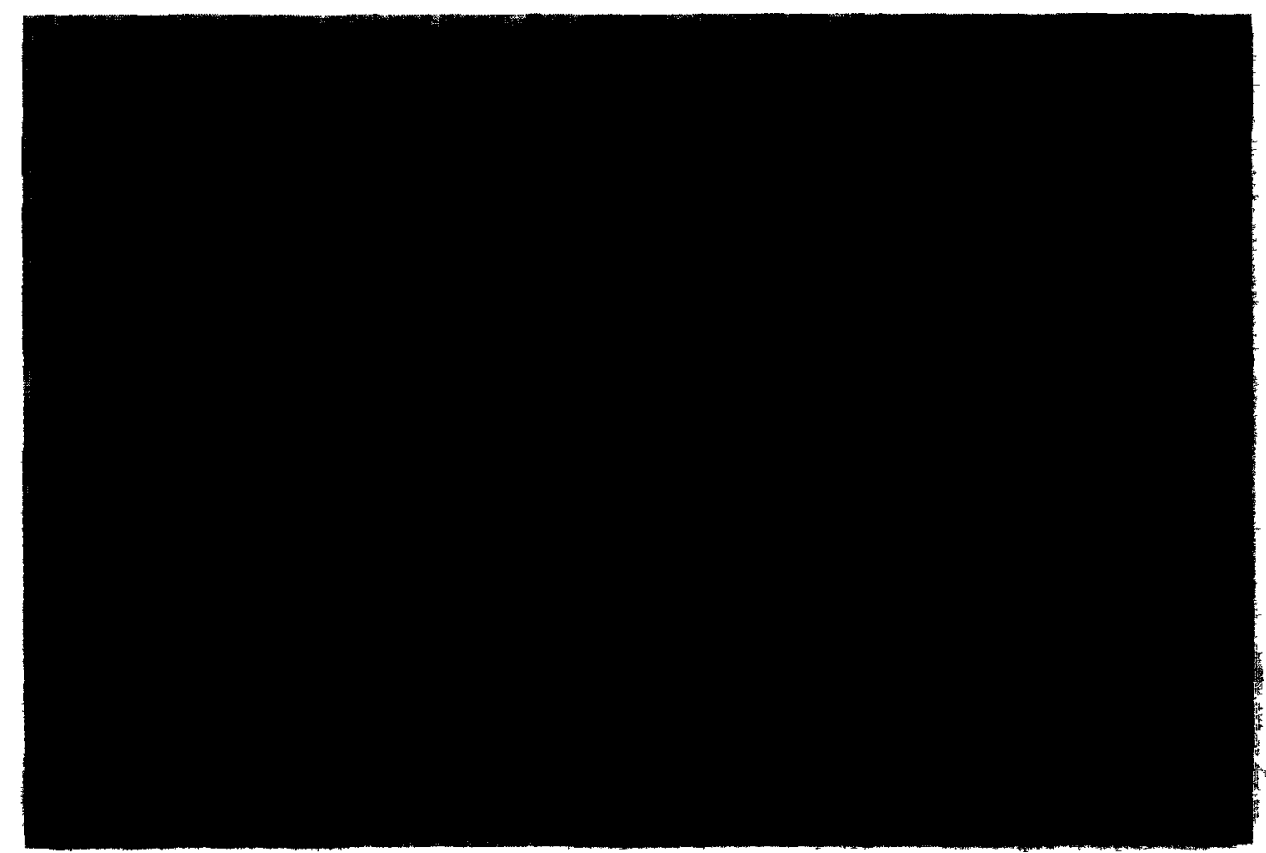

Fig 5 Cross-section through a 32-day muscle graft The muscle fibers are generally mature in appearance, but as is typical in mature regenerated muscle fibers, occasional central nucleı persist $H$ and E,, 100 


\section{GLUCOSE-6-PHOSPHATE DEHYDROGENASE}

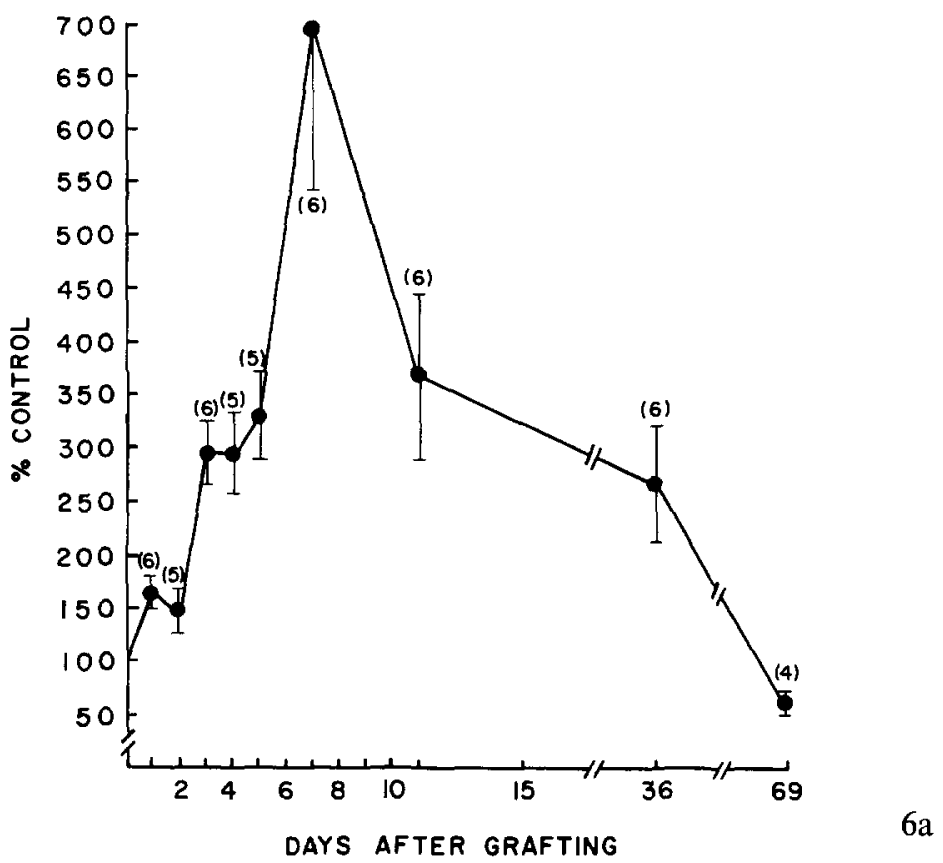

HEXOKINASE

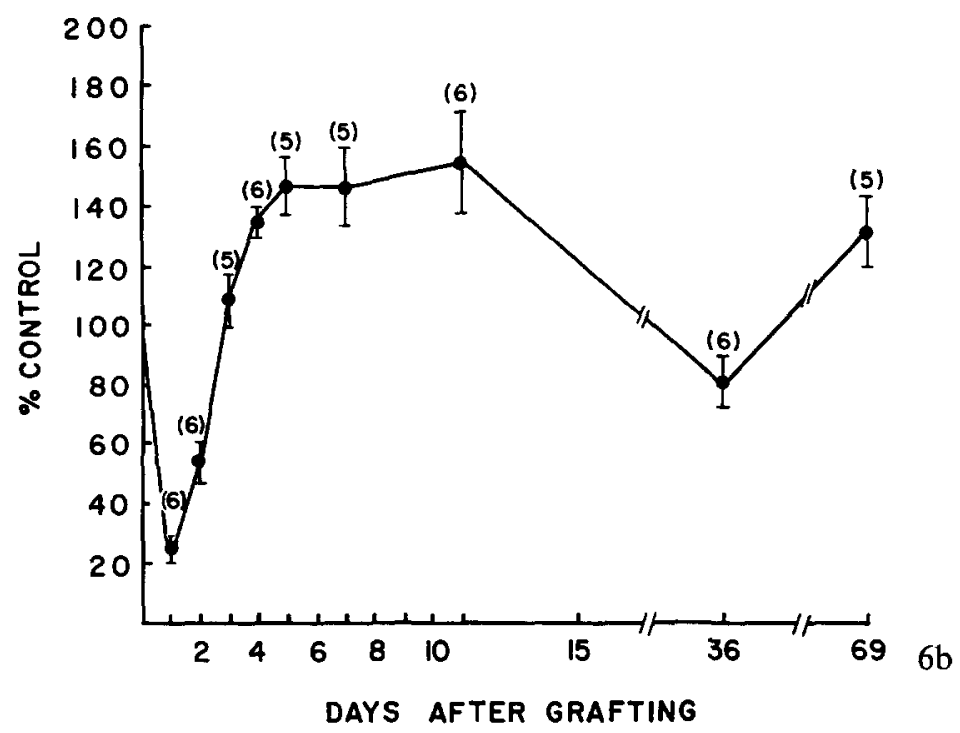

day 6 (F1g 6b) In contrast, phosphorylase decreased dramatically to about $5 \%$ of control on day 1 and reached only about $20 \%$ of control by day 69 (Fig 6c) Phosphofructokınase also decreased to about $5 \%$ of control on day 1 , began to increase on day 11 , and reached about $65 \%$ of control on day 69 (Fig. 6d) $\alpha$-Glycerophosphate dehydrogenase followed a pattern sımılar to that of phosphofructokınase ( $F_{1} g$ 6e), 


\section{PHOSPHORYLASE}

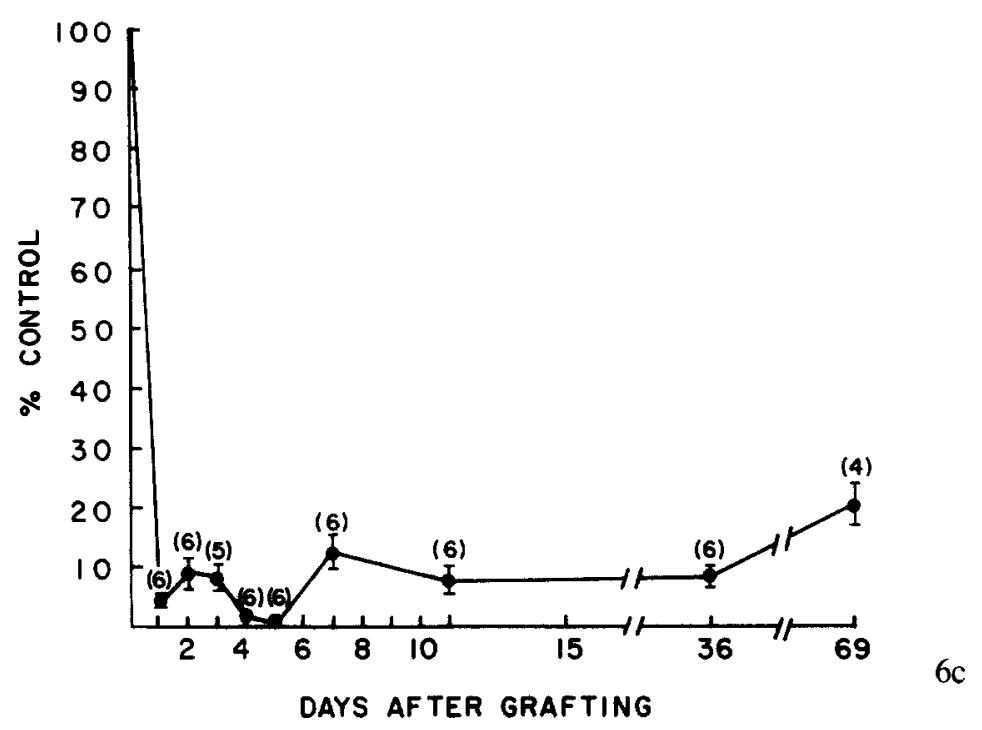

PHOSPHOFRUCTOKINASE

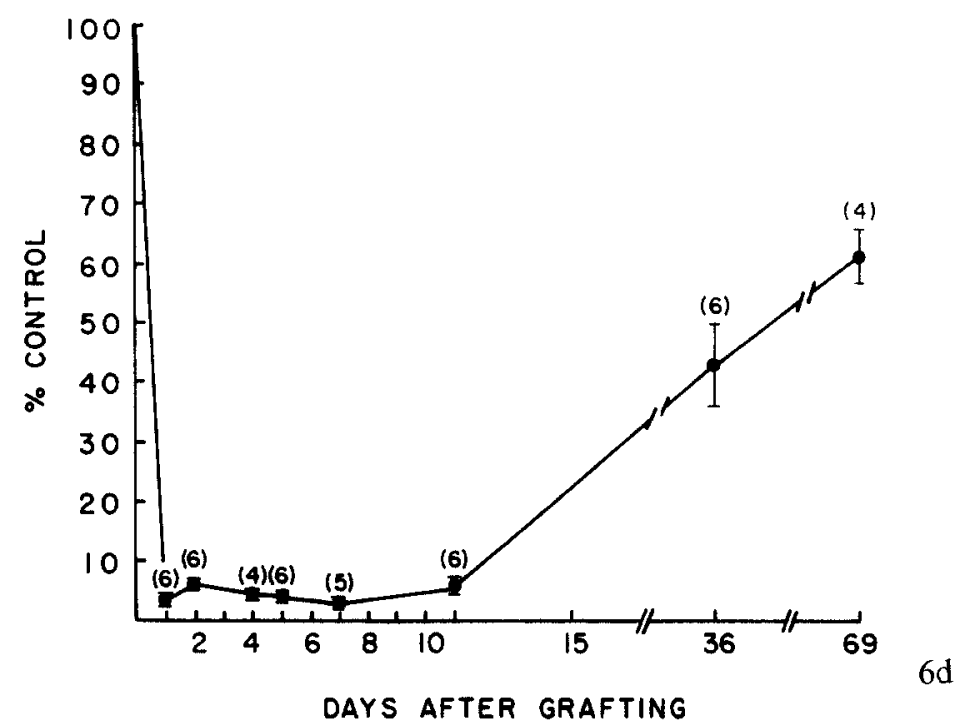

In that its activity decreased strikıngly on day 1 and began to rise on day 11 , reaching about $40 \%$ of control by day 69 Lactate dehydrogenase decreased to $12 \%$ of control by day 1 , began to increase after day 2, and attained about $65 \%$ of control by day 69 (Fig 6f) Simılarly, pyruvate kınase dropped to $5 \%$ of control by day 1, began to rise immediately thereafter, and was $75 \%$ of control on day 69 (Fig. 6g) Creatıne kınase (Fig 6h) and adenylate kınase (Fig 61) displayed sımılar patterns Their activities decreased to about $8 \%$ of control on day 1 , began to increase on day 4 , reaching values of $130 \%$ and $80 \%$ of control, respectively, by day 69 


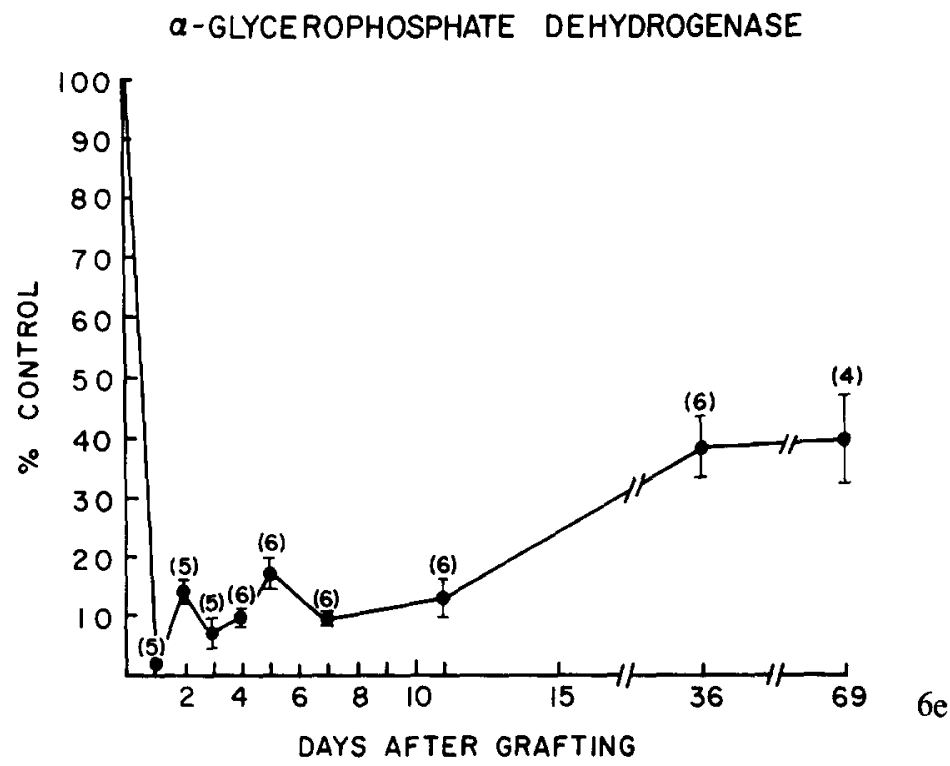

LACTATE DEHYDROGENASE

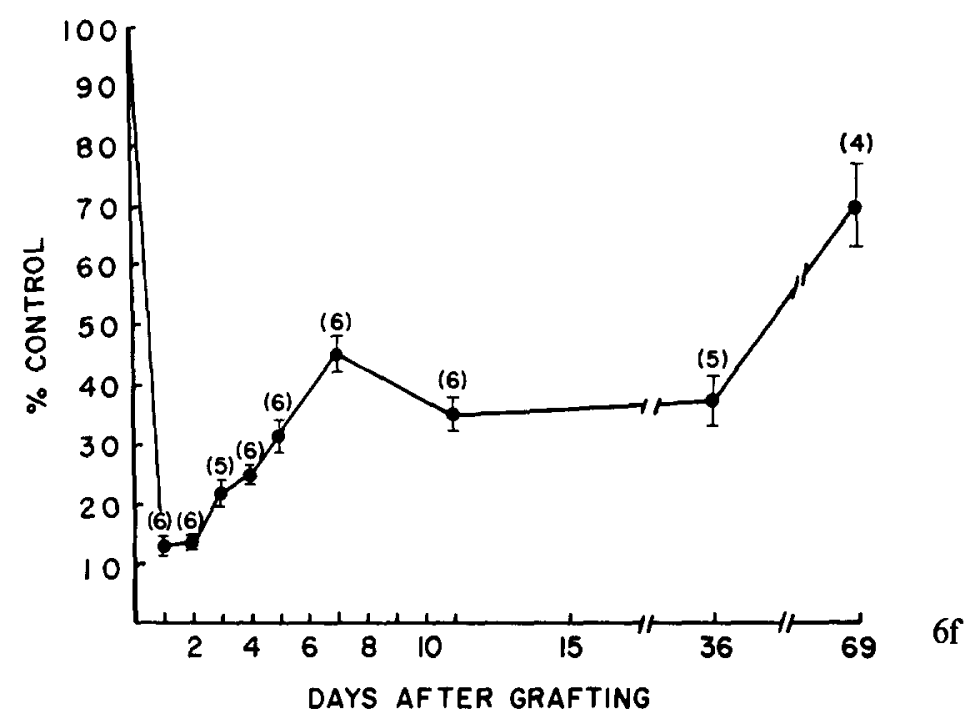

These enzyme activities can be classified into 3 groups with respect to their regeneratıve patterns (1) initial increase in activity hexokınase, glucose-6-phosphate dehydrogenase, (2) initial reduction with farlure to recover to control values phosphorylase, phosphofructokınase, $\alpha$-glycerophosphate dehydrogenase, and (3) initial decrease followed by approximate return to control levels pyruvate kınase, lactate dehydrogenase, creatıne kınase and adenylate kınase

\section{DISCUSSION}

Marcaine-treated free muscle grafts are proving to be useful models for the study 


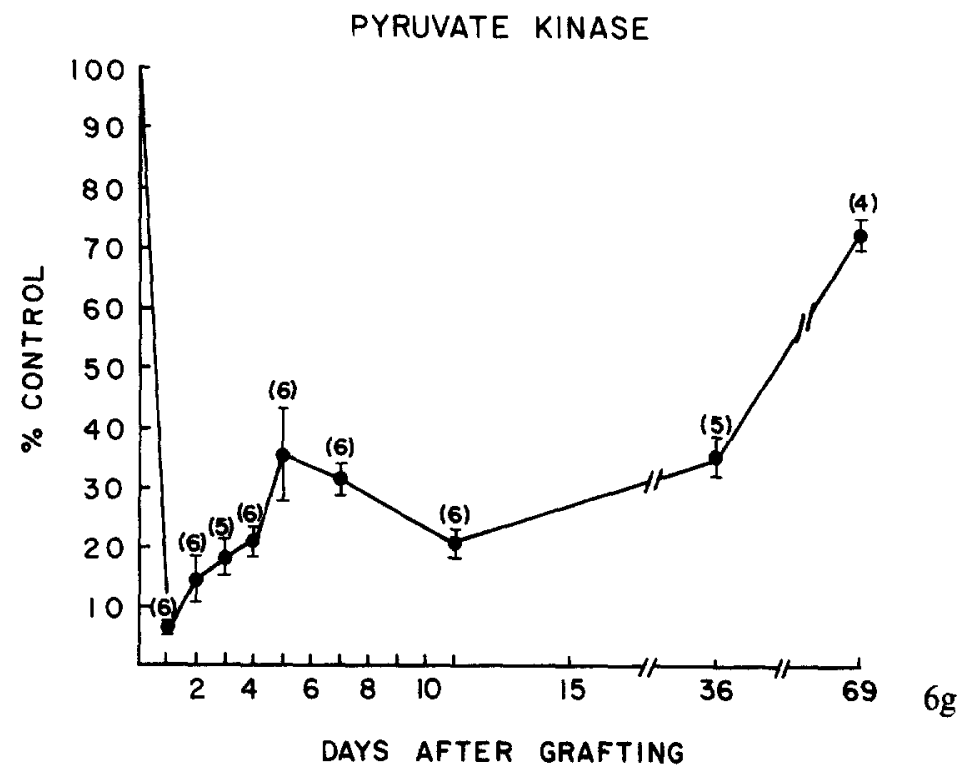

CREATINE KINASE

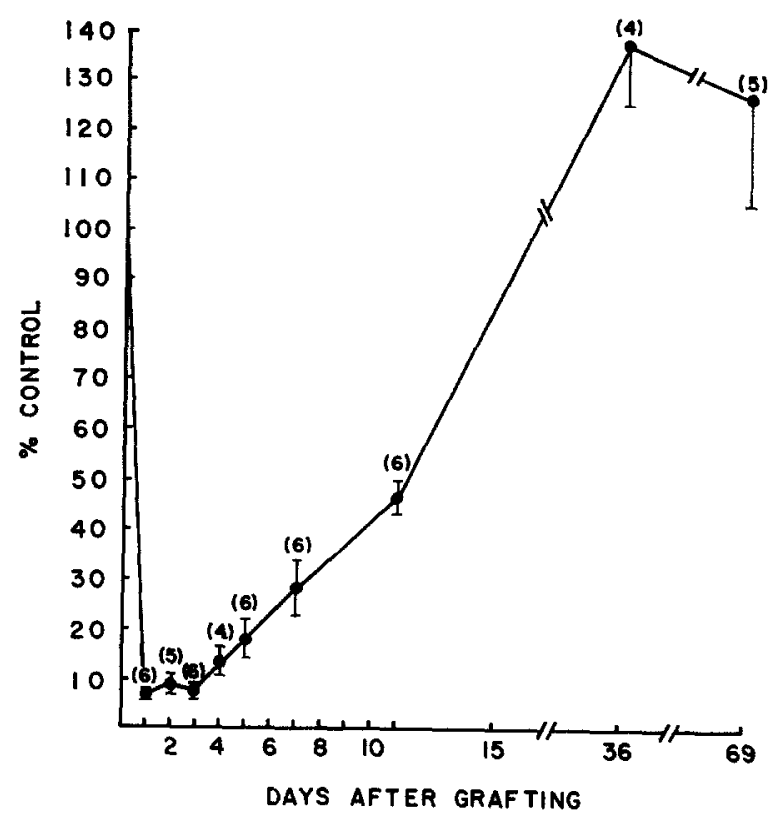

$6 \mathrm{~h}$

of the physiological and biochemical properties of regenerating skeletal muscles With this model it has been possible to monitor the development of contractile properties of regenerating muscle fibers without the interference of contractile input of surviving muscle fibers (Carlson and Gutmann 1976b). In this study we employed the same model to examıne the developmental patterns of glycolytic enzyme actıvities in regeneratıng muscle

There is reasonable correlation between the biochemical and morphological 


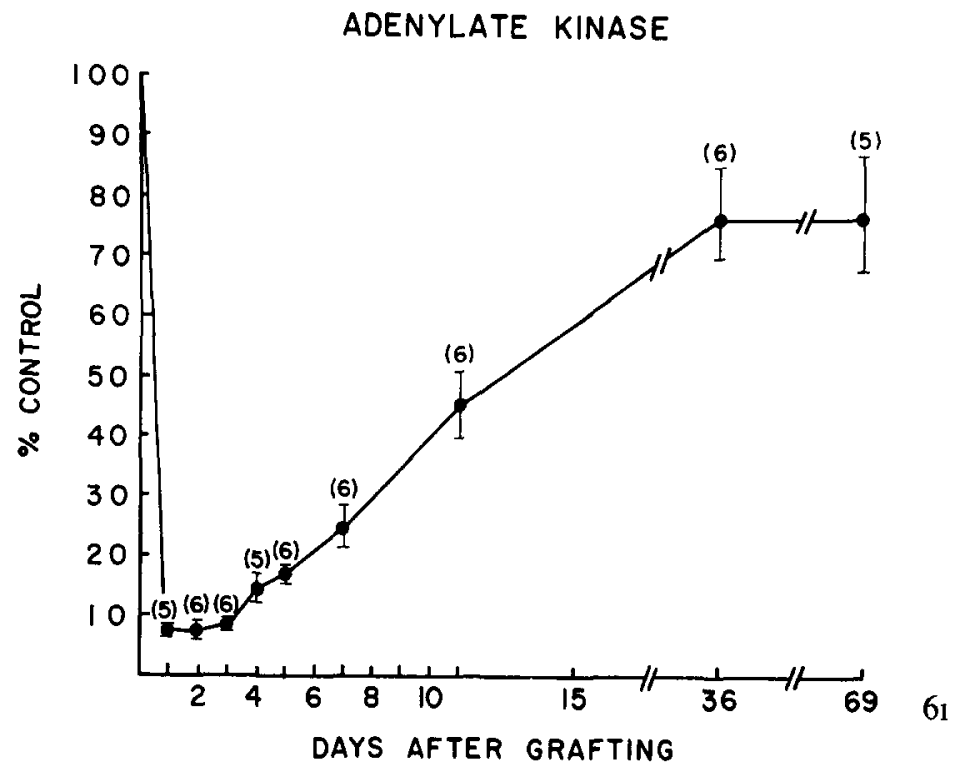

Fig 6 Enzyme activities in rat extensor digitorum longus muscles after Marcaine treatment and orthotopic free graftıng (a) glucose-6-phosphate dehydrogenase, (b) hexokınase, (c) phosphorylase, (d) phosphofructokınase, (e) a-glycerophosphate dehydrogenase, (f) lactate dehydrogenase, (g) pyruvate kınase, (h) creatıne phosphokınase, (1) adenylate kınase Numbers in parentheses are numbers of rats Experimental procedures are described in the text

observations on muscle grafts Thus, on day 2 , a large central zone of the graft is ischemic, while the presence of myoblastic cells between this area and the periphery is noteworthy (Fig 2, cf Carlson 1976) The dramatic decrease in most enzyme activities presumably reflects increased protein catabolısm in ischemic tissue undergoing degeneration Loss of glycolytic enzymes was also observed in ischemic skeletal muscle (Archangel1, Digiesı, Masala, Serra and Congiu 1973)

The enhanced activities of glucose-6-phosphate dehydrogenase and hexokinase are associated with elevated activity of the pentose phosphate pathway (Figs 6a and b, cf Beaconsfield and Carp1 1964, Rifenberick, Koskı and Max 1974, Wagner, Kauffman and Max 1977), and probably reflect accelerated glucose utilization for the production of nucleic acıds (Beaconsfield and Readıng 1964) and lipıds in proliferatıng myoblastic cells In this regard, increased RNA content has been noted in a number of studies on muscle regeneration (Gallucci, Novello, Margreth and Aloss 1966, Susheela, Hudgson and Walton 1969, Carlson 1970, Neerunjun and Dubowitz 1974b) Furthermore, Warshaw, Barrett and Coyne (1976) have provided evidence for a relationship between pentose phosphate pathway actıvity and growth in chick heart muscle cells

The accelerated activities of lactate dehydrogenase (Fig 6f), pyruvate kınase (Fig 6g), creatıne kınase (Fig $6 \mathrm{~h}$ ) and adenylate kınase ( $F_{1} g$ 61) beginnıng at the fourth or fifth day may be a manifestation of the increased amount of regeneration noted durıng this period (Fig 3) Creatıne kınase and adenylate kınase actıvitıes increase in association with the fusion of myoblasts in culture (Shainberg, Yagil and Yaffe 1971, 
Morris and Cole 1972) Furthermore, creatıne kınase accumulates rapidly after the 17th day of gestation in rat muscles (Z1ter 1974)

By day 8 after graftıng there are no surviving original muscle fibers and the regenerative response appears maximal (Fig 4) It is at this time that glucose-6-phosphate dehydrogenase is at its highest activity (Fig 6a) and basophilia is most prominent (Carlson 1976) The later increases in phosphofructokınase (Fig 6d) and $a$-glycerophosphate dehydrogenase ( $\mathrm{F}_{1 \mathrm{~g}} \mathrm{6e}$ ) presumably reflect maturation of regeneratıng muscle fibers ( $F_{1} g$ )

The fallure of phosphorylase (Fig 6c) to show significant recovery within the 69-day period of these experiments is interesting In a previous histochemical study of free grafts, phosphorylase appeared to be the most severely affected enzyme, although it made some recovery (Carlson and Gutmann 1975) Phosphorylase was the first enzyme to decrease after physical injury to muscle (Smith 1965) and was decreased withın $24 \mathrm{hr}$ after mincing and transplantation of muscle in hamsters (Neerunjun and Dubowitz, 1974b) A substantial decrease of phosphorylase was also noted following 3 injections of Marcaine plus hyaluronidase (Wagner, Max, Grollman and Koskı 1976) Phosphorylase was not histochemically detectable in regenerating muscle unt 1 the fibers became histologically normal (Smith 1965) In the present study, 69 days after graftıng (Fig 4) many regenerated fibers stıll had central nucleı, indicatıng that regeneration was not complete

One possible source of contamination of enzymatic activities is infiltration of the muscle by phagocytic cells However, in a recent study, glucose-6-phosphate dehydrogenase was shown histochemically to be localized primarily in skeletal muscle fibers rather than in interstitial cells following intramuscular administration of Marcaine (Wagner, Kauffman and Max 1977) Similar histochemical localization of glucose-6-phosphate dehydrogenase in regeneratıng muscle fibers has been observed by Snow (1973) and by Smith (1965) Thus it appears unlikely that cellular infiltration significantly influenced the enzymatic activities in muscle supernatants

Enzymatic changes associated with development of muscle both in vivo and in tissue culture have been described in a number of species Comparison of our data with these results has revealed interesting similarities and differences For example, the most strikıng early change observed in our study was increased activity of glucose-6phosphate dehydrogenase and hexokınase (F1g $6 \mathrm{a}$ and b) Rat skeletal muscle glucose6-phosphate dehydrogenase (Hommes and Wilmink 1968) and rabbit skeletal muscle hexokınase (Stave 1964) increased perınatally, while glucose-6-phosphate dehydrogenase activity increased about 3-fold, and hexokinase actıvity was unchanged in tıssue culture studies of chick embryonıc muscle (Schudt, Gaertner, Dolkın and Pette 1975) Similarly, hexokınase activity was unchanged during in vivo development of chıck skeletal muscle (Hauschka 1968) It is lıkely, however, that hexokınase had already attained optimal activity in these latter two studies

Although creatine kınase and adenylate kınase (Fig 6h, 1) increased more rapidly than lactate dehydrogenase and pyruvate kınase (Fig $6 \mathrm{f}$ and $\mathrm{g}$ ) in regeneratıng muscle, in developing rabbit muscle these enzymes increased in parallel (Stave 1964) In the present study, phosphofructokınase activity increased durıng the second week 
of regeneration (Fig 6d) In contrast, in developing rat (Hommes and Wilmınk 1968) and chick (Hauschka 1968) skeletal muscle, little change in phosphofructokınase activity occurred from pre- to postnatal development On the other hand, a very early rise in activity occurred in tissue culture (Schudt, Gaertner, Dolkin and Pette 1975), as was the case in fetal muscle of the rhesus monkey in which activity was 3-5 times greater than the adult (Beatty, Young and Bocek 1976) The finding by Gallucc, Novello, Margreth and Aloisi (1968) that phosphofructokınase actıvity was higher in 15-21 day minced muscle implants than in 2-3 week old neonatal muscle is in contrast to our results and remains unexplained

Phosphorylase increased rapidly in chicks after hatching (Hauschka 1968, Bass, Lusch and Pette 1970), before birth in primates (Bocek, Basinger and Beatty 1969), and in developing chick and rat embryonic muscle in tissue culture (Shaınberg, Yagil and Yaffe 1972, Schudt, Gaertner, Dolken and Pette 1975), but recovered poorly in the present experıments (Fig 6c) In support of our results are those of Galluccı, Novello, Margreth and Aloss (1966) who found less total phosphorylase and glycogen synthetase in regenerating skeletal muscle than neonatal muscle

These observations suggest that regeneratıng muscle does not exactly recapitulate the ontogenetıc pattern, although there are strikıng sımılarities between embryonıc and regeneratıng muscle in morphological characteristics (Studitsky and Striganova 1951, Hudgson and Field 1972), in the development of contractıle properties (Carlson and Gutmann 1976b), in neuromuscular relations (Mong 1975, Carlson and Gutmann 1976a), and in the establishment of histochemical fiber types (Carlson and Gutmann 1975, Mong 1975) A simılar biochemical picture is seen in liver regeneration where an enzymatic profile unıque to regeneratıon was consıdered to confer biological advantages upon both the regenerating cell and the host (Weber 1975) It is possible that the observed biochemical departures from the normal ontogenetic pattern represent adaptations to a harsher metabolic environment than that found in the normally developing limb This is particularly true with respect to the blood supply, which is present in abundance in and around embryonic muscles from the time their individual anlagen first become discrete entities There is no direct blood supply to the myoblastic cells during their period of activation in free muscle grafts and in minced preparations

An unanswered question concerns sources of metabolic energy which permit muscle to survive the early period of degeneration and support subsequent regeneration (Gallucci, Novello, Margreth and Aloısı 1966, Snow 1973) In a previous report we showed that glycolysis survives Marcaine plus hyaluronidase treatment (without orthotopic free graftıng) and is probably sufficient to support the early stages of regeneration in the face of obliterated oxıdative metabolısm (Rıfenberıck, Koskı and Max 1974, Wagner, Max, Grollman and Koskı 1976) The combination of Marcaine plus free graftıng is apparently so devastatıng that most glycolytic enzyme actıvities are markedly reduced In the early stages of Marcaine-induced muscle regeneration, the contraction tımes are very slow (Carlson and Gutmann 1976b), a disarray of contractle apparatus predominates (E C B Hall-Craggs, personal communication) and actomyosin ATPase activity is severely decreased (Wagner, Cornblath and Max, unpublished) Therefore, a regeneratıng muscle fiber is unlıkely to utılıze energy for contraction, and a low level 
of glycolysis may be sufficient to provide energy for biosynthetic processes in mononuclear premyoblastic and myoblastic cells and in non-contractıng muscle fibers Furthermore, since the pentose phosphate pathway can provide trioses which can enter the glycolytic scheme at triose phosphate isomerase, it seems feasible that the enhanced activity of the pentose pathway may represent a bypass around phosphofructokinase to permit glycolysis to proceed until the full recovery of glycolytic and oxidative enzymes at a later stage of regeneration

\section{REFERENCES}

Archangel1, P, V Digiesı, B Masala, M V Serra and A Conglu (1973) Metabolism of skeletal muscle following incomplete 1schemia, Angtology, 24 114-122

Bass, A , G Lusch and D Pette (1970) Postnatal differentiation of the enzyme activity pattern of energy-supplyıng metabolısm in slow (red) and fast (white) muscles of chicken, Eur $J$ Biochem, $13 \quad 289-292$

Beaconsfield, P and A Carpı (1964) Localization of an infectious lesion and glucose metabolısm via the pentose phosphate pathway, Nature (Lond), $201 \quad 825-827$

Beaconsfield, $P$ and $H$ N Reading (1964) Pathways of glucose metabolısm and nucleic acid synthesis, Nature (Lond), 202 464-466

Beatty, C H , M K Young and R M Bocek (1976) Control of glycolysis in skeletal muscle from fetal rhesus monkeys, Pediat Res, 10 149-153

Benoit, P W and W D Belt(1970)Destruction and regeneration of skeletal muscle after treatment with a local anesthetic, bupivacaine (Marcaine), J Anat, 107 547-556

Bocek, R M, G M Basinger and C H Beatty (1969) Glycogen synthetase, phosphorylase, and glycogen content of developing rhesus muscle, Pediat Res , 3 525-531

Carlson, B M (1970) Histological observations on the regeneration of mammalian and amphibian muscle, In A Mauro, S A Shafiq and A T Milhorat (Eds), Regeneration of Strrated Muscle, and Myogenesis (Proceedings of an International Conference, New York, 1969) (International Congress Series, No 218), Excerpta Medica, Amsterdam, pp 38-72

Carlson, B M (1972) The Regeneration of Minced Muscles, Monographs in Devel Biol, Vol 4, S Karger, Basel, p 128

Carlson, B M (1976) A quantitative study of muscle fiber survival and regeneration in normal, predenervated and Marcaine-treated free muscle grafts in the rat, Exp Neurol, 52 421-432

Carlson, B M and E Gutmann (1975) Regeneration in free grafts of normal and denervated muscles in the rat Morphology and histochemistry, Anat Rec, $183 \quad 47-62$

Carlson, B M and E Gutmann (1976a) Contractıle and histochemical properties of sliced muscle grafts regeneratıng in normal and denervated rat limbs, Exp Neurol, 50 319-329

Carlson, B M and E Gutmann (1976b) Free grafting of the extensor digitorum longus muscle in the rat after Marcaine pre-treatment, Exp Neurol, 53 82-93

Galluceı, V , F Novello, A Margreth and M Aloisı (1966) Biochemical correlates of discontınuous muscle regeneration in the rat, Brit $J$ exp Path , 47 215-227

Hall-Craggs, E C B (1974) Rapid degeneration and regeneration of a whole skeletal muscle following treatment with bupivacaine (Marcaine), Exp Neurol, 43 349-358

Hall-Craggs, E C B and H Singh-Seyan (1975) Histochemical changes in innervated and denervated skeletal muscle fibers following treatment with bupivacaine (Marcaine), Exp Neurol, 46 345-354

Hauschka, S D (1968) Clonal aspects of muscle development and the stability of the differentiated state, In H Ursprung (Ed), The Stability of the Differentiated State, Springer-Verlag, Berln, pp $37-57$

Holloszy, J O and L B Oscan (1969) Effect of exercise on $\alpha$-glycerophosphate dehydrogenase activity in skeletal muscle, Arch Biochem Biophys, $130 \quad 653-656$

Hommes, F A and G W Wilmink (1968) Developmental changes of glycolytic enzymes in rat brain, liver and skeletal muscle, Biol Neonat, 12 181-193

Hudgson, $P$ and E J Field (1972) Regeneration of muscle In G H Bourne (Ed), The Structure and Function of Muscle, 2nd ed, Vol 11, pp 312-363 
Jırmanova, I and S Thesleff (1972) Ultrastructural study of experımental muscle degeneration and regeneration in the adult rat, $Z$ Zellforsch, 131 77-97

Lowry, O H, N J Rosebrough, A L Farr and R J Randall (1951) Protein determination with the Folın phenol reagent, $J$ biol Chem, $193 \quad 265-275$

Mastaglıa, F L , R L Dawkıns and J M Papadımıtrıou (1975) Morphological changes in skeletal muscle after transplantation A light and electron microscopic study of the initial phases of degeneration and regeneration, $J$ neurol $S c t, 25 \quad 227-247$

Max, S R and E X Albuquerque (1975) Neurotrophic regulation of acetylcholinesterase in regenerating skeletal muscle, Exp Neurol, $49 \quad 852-857$

Max, S R and D H Rifenberick (1975) Cholıne acetyltransferase and cholınesterase in skeletal muscle regeneration, $J$ Neurochem, 24 771-773

Mong, F S F (1975) Histological and histochemical studies on the nervous influence on mınced muscle regeneration of triceps surae of the rat, $\mathrm{Ph} \mathrm{D}$ Thesis, University of Michigan, $\mathrm{p} 159$

Morris, G E and R J Cole (1972) Cell fusion and differentiation in cultured chick muscle cells, Exp Cell Res, 75 191-199

Neerunjun, J S and V Dubowitz (1974a) Muscle transplantation and regeneration in the dystrophic hamster Part I Histological studies, J neurol Sct, $23 \quad 505-519$

Neerunjun, J S and V Dubowitz (1974b) Muscle transplantation and regeneration in the dystrophic hamster Part 2 Histochemical studies, J neurol Sct, 23 521-536

Paetkau, V and H A Lardy (1967) Phosphofructokınase Correlation of physical and enzymatic properties, $J$ biol Chem, 242 2035-2042

Reznık, M (1968) Etude autoradıographıque du muscle strıe en regéneratıon in vivo, $J$ Embryol Exp Morph, 19 283-297

Reznık, M (1973) Current concepts of skeletal muscle regeneration, In C M Pearson (Ed), The Striated Muscle, pp 185-225

Rifenberıck, D H , C L Koskı and S R Max (1974) Metabolıc studıes of skeletal mucle regeneratıon, Exp Neurol, 45 527-540

Shaınberg, A , G Yagıl and D Yaffe (1971) Alteratıons of enzymatıc actıvitıes durıng muscle dıfferentiation in vitro, Devel Btol, 25 1-29

Schudt, C , U Gaertner, G Dolken and D Pette (1975) Calcıum-related changes of enzyme activities in energy metabolısm of cultured embryonıc chıck myoblasts and myotubes, Eur $J$ Biochem, $60 \quad 579-586$

Shonk, C E and G E Boxer (1964) Enzyme patterns in human tıssues I Methods for the determınation of glycolytic enzymes, Cancer Res , 24 709-721

Smith, A F (1972) Separation of tissue and serum creatıne kınase isoenzymes on polyacrylamide gel slabs, Clin Chim Acta, 39 351-356

Smith, B (1965) Histochemical changes in muscle necrosis and regeneration, $J$ Path Bact, 89 139-143

Snow, M H (1973) Metabolic actıvity durıng the degeneratıve and early regenerative stages of minced skeletal muscle, Anat Rec, $176 \quad 185-204$

Snow, M H (1977a) Myogenıc cell formation in regeneratıng rat skeletal muscle injured by mıncıng I A fine structural study, Anat Rec, 188 181-200

Snow, M H , (1977b) Myogenic cell formation in regeneratıng rat skeletal muscle injured by mincing II An autoradiographic study, Anat Rec, 188 201-218

Stave, U (1964) Age-dependent changes of metabolısm I Studıes of enzyme patterns of rabbit organs, Biol Neonat, $6 \quad 128-147$

Studitsky, A M and A R Striganova (1951) Restorative Processes in Skeletal Muscle (Russian), Izdatel Akad Nauk S S S R, Moscow, p 172

Susheela, A K , P Hudgson and J N Walton (1969) Histological and histochemical studies of experımentally-induced degeneration and regeneration in normal and dystrophic mouse muscle, $J$ neurol $\mathrm{Scl}, 9$ 423-442

Thomas, J A , K K Schlender and J Larner (1968) A rapid filter paper assay for UDP glucose-glycogen glucosyltransferase, including an improved biosynthesis of UDP-14C-glucose, Anal Biochem, 25 486-499

Uyeda, K and E Racker (1965) Regulatory mechanısms in carbohydrate metabolism VII Hexokınase and phosphofructokinase, $J$ biol Chem , $240 \quad 4682-4688$

Wagner, K R , B M Carlson and S R Max (1976) Developmental patterns of glycolytıc enzymes in regeneratıng rat skeletal muscle, Neuroscl Abstr, 2205 
Wagner, K R, S R Max, E M Grollman and C L Koskı (1976) Glycolysıs in skeletal muscle ILgeneration, Exp Neurol, $52 \quad 40-48$

Wagner, K R , F C Kauffman and S R Max (1976) Rapid induction of glucose-6-phosphate d"hydrogenase in regeneratıng skeletal muscle, Fed Proc , 36929

Warshaw, J B , L Barrett and B J Coyne (1976) Effect of pH alteration on growth and glucosc oxidation in myoblast cultures, Exp Cell Res, 99 278-284

Weber, G (1975) Blochemical strategy of the regeneratıng liver cell, In $\mathbf{R}$ Lesch and W Reuitcr (Eds), Liver Regeneration After Experimental Injurv, Stratton Intercontinental Medical Book Corp, New York, pp 103-117

Ziter, F A (1974) Creatıne kınase in developing skeletal and cardiac muscle of the rat, Lip Neurol, $43 \quad 539-546$ 